\title{
Slope failure hazard in Canada's Atlantic Provinces: a review
}

\author{
Ian Spooner ${ }^{1^{*}}$, Martin Batterson ${ }^{2}$, Norm Catto ${ }^{3}$, David Liverman ${ }^{2}$, Bruce E. \\ Broster $^{4}$, Kim Kearns 5 , Fenton Isenor ${ }^{6}$, And G. Wayne McAskill ${ }^{7}$
}

1. Department of Earth and Environmental Science, Acadia University, Wolfville, Nova Scotia B0P 1X0, Canada

2. Geological Survey of Newfoundland and Labrador, Department of Natural Resources, Government of

Newfoundland and Labrador, PO Box 8700, St. John's, Newfoundland and Labrador A1B 4J6, Canada

3. Department of Geography, Memorial University of Newfoundland, St. John's, Newfoundland and Labrador

A1B 3X9, Canada

4. Department of Earth Sciences, University of New Brunswick, Fredericton, New Brunswick E3B 5A3, Canada

5. ESRI, 380 New York St., Redlands, California 92373-8188, USA

6. Cape Breton University, P.O. Box 5300, 1250 Grand Lake Road, Sydney, Nova Scotia B1P 6L2, Canada

7. Nova Scotia Department of Transportation and Public Works, 107 Guysborough Road, Fall River, Nova Scotia

B2T 1J6, Canada

${ }^{\star}$ Corresponding author $<$ ian.spooner@acadiau.ca $>$

Date received 26 February 2012 Date accepted 30 November 2012

\begin{abstract}
Slope failures present a hazard around the world, with considerable impact on communication/ transportation corridors, resource sectors, and coastal and urban development. Although poorly documented in much of Atlantic Canada, mass movements are known to have resulted in 71 fatalities in Newfoundland. In the Ferryland, Newfoundland, disaster of around 1823, 42 fishermen were reportedly killed when a cave roof collapsed onto them. Debris floods and flows are widespread in areas of higher relief in both Newfoundland and Cape Breton Island, and tend to be most hazardous for highway engineering and community development. Rotational slumps in glaciomarine clays are evident along the major river valleys of Labrador and are an important consideration during hydroelectric development. In other areas of Atlantic Canada, earthflows affect transportation routes and involve movement of saturated sediment during spring thaw. Along the Gulf of St. Lawrence, Northumberland Strait and the Bay of Fundy coastlines, friable rocks, glaciotectonic activity, frost wedging, and coastal erosion have resulted in many small failures and incremental retreat of coastal cliffs.

Ongoing climate change will have an impact on slope failure activity. Increasing summer frequency and intensity of thunderstorms and hurricane events, increased winter precipitation in some locations, and possible erratic freeze-thaw events would result in an increase in debris flows triggered by precipitation, and rockfalls triggered by freeze-thaw. Human utilization of coastal areas is also contributing to the frequency and hazard of slope failures across Atlantic Canada.
\end{abstract}

\section{RÉSUMÉ}

Les ruptures de versant représentent un danger partout dans le monde et ont une incidence considérable sur les corridors de communication ou de transport, les secteurs des ressources et l'aménagement côtier et urbain. Bien qu'ils soient mal documentés dans une bonne partie du Canada atlantique, ces mouvements de masse sont réputés pour avoir causé 71 décès à Terre-Neuve. Dans la catastrophe de Ferryland, à Terre-Neuve, 
vers 1823, 42 pêcheurs auraient été tués lorsque le plafond d'une caverne s'est effondré sur eux. Les inondations et coulées de débris sont courantes dans les zones de relief élevé à Terre-Neuve et à l'île du Cap-Breton, et elles tendent à être très dangereuses pour la conception des routes et le développement des localités. Des glissements rotationnels dans les argiles glaciomarins sont manifestes le long des vallées fluviales importantes du Labrador et sont un facteur important à considérer lors d'aménagements hydroélectriques. Dans d'autres régions du Canada atlantique, les coulées de terre perturbent les routes de transport et entraînent le mouvement de sédiments saturés durant le dégel printanier. Le long des côtes du golfe du Saint-Laurent, du détroit de Northumberland et de la baie de Fundy, des roches friables, de l'activité glaciotectonique, de la gélifraction et de l'érosion côtière ont donné lieu à de nombreuses petites ruptures et au recul graduel des falaises côtières.

Leschangements climatiques en coursauront uneincidencesurles ruptures deversant.Lafréquenceetl'intensité accrues desorages et desouragans pendantl'été,l'augmentation desprécipitationshivernales danscertainsendroitset la possibilité de gels-dégels erratiques pourraient se traduire par une augmentation des coulées de débris déclenchées par les précipitations et des éboulements déclenchés par les gels-dégels. L'utilisation humaine des zones côtières contribue également à la fréquence et à la dangerosité des ruptures de versant dans l'ensemble du Canada atlantique.

[Traduit par la redaction]

\section{INTRODUCTION}

Some authors consider landslides not to be a major hazard in Atlantic Canada (Cruden et al. 1989; Evans 2001). In a compilation of Canadian landslide disasters, Evans (2001), who defined a disaster as "an incident with three or more fatalities", showed that only one such event out of 45 occurred in the region. However, it is misleading to assume that landslides are insignificant in the area and inappropriate not to recognize potential risks to life and property (Fig. 1). Liverman et al. (2001) and Batterson et al. (2006) reviewed geological hazards in Newfoundland and tabulated known landslides there. Additional research, documented here, indicates that 29 to 71 fatalities in Newfoundland alone may have occurred from landslides, as well as 68 from snow avalanches (Liverman et al. 2001, 2003; Batterson et al. 2006). In Nova Scotia, five fatalities associated with snow avalanches have been documented (Isenor et al. 2005; Spooner et al. 2010).

Our objective is to summarize the variety of slope failure processes that are active in Atlantic Canada, with examples of recent and/or significant events. We also provide an overview of slope failure research in the region and indicate where further study is warranted. We demonstrate that slope failures are common and have a significant impact on communication/transportation corridors, the resource sector, coastal and urban development, and other activities. We use the terms slope failure and mass wasting interchangeably to describe the downslope movement of rock debris and soil in response to gravitational stresses. We use the term landslide when the responsible mechanisms and the velocity of movement allow the slope failure to be classified in detail. This review is restricted to onshore impacts, although the offshore is equally prone to slope movements. We review slope failures province-by-province, emphasizing the characteristic slope failure styles for each (Fig. 1). We do not include snow avalanche hazards in this review.

\section{SLOPE FAILURE IN NEWFOUNDLAND AND LABRADOR}

A variety of slope failure types has occurred in Newfoundland and Labrador, including sackung; rockfalls; debris torrents and floods; channelized debris flows and debris avalanches; rotational slumps; and gelifluction creep. Many incidents have been documented, with over 80 having been recorded as impacting communities and infrastructure (Batterson et al. 2006). Some have been fatal, including two landslides in St. John's (1936 and 1948) and the 1973 Harbour Breton landslide that killed four children. Landslides involving rotational slumping of large masses of sediment have been recorded on the west coast of the island, including events at Port au Port East in 1994; near Journois, St. George's Bay in 1996; at Daniel's Harbour in 2007-2008; and at Trout River in 2009 (Fig. 1). The last two examples caused no loss of life, but resulted in considerable property damage and the relocation of several residences. Other slope failures have occurred in remote areas, where they have had little impact on society, but may need to be considered if development takes place in the future.

\section{Sackungen}

A "sackung" (plural sackungen) is a deep-rooted, generally slow-moving slope failure involving large volumes of bedrock. A sackung is identified on aerial photographs by a series of linear scarps that face up-slope; these are called "anti-slope scarps". Grant $(1974,1987)$ identified 24 examples, mostly developed in ultramafic rocks in western Newfoundland. The slowness of motion, combined with the absence of residential or commercial development in areas where these occur, limit their significance as a hazard. In times of exceptional rainfall, movement may accelerate (Evans and Clague 2003), and a rapid collapse into water might generate displacement waves. 


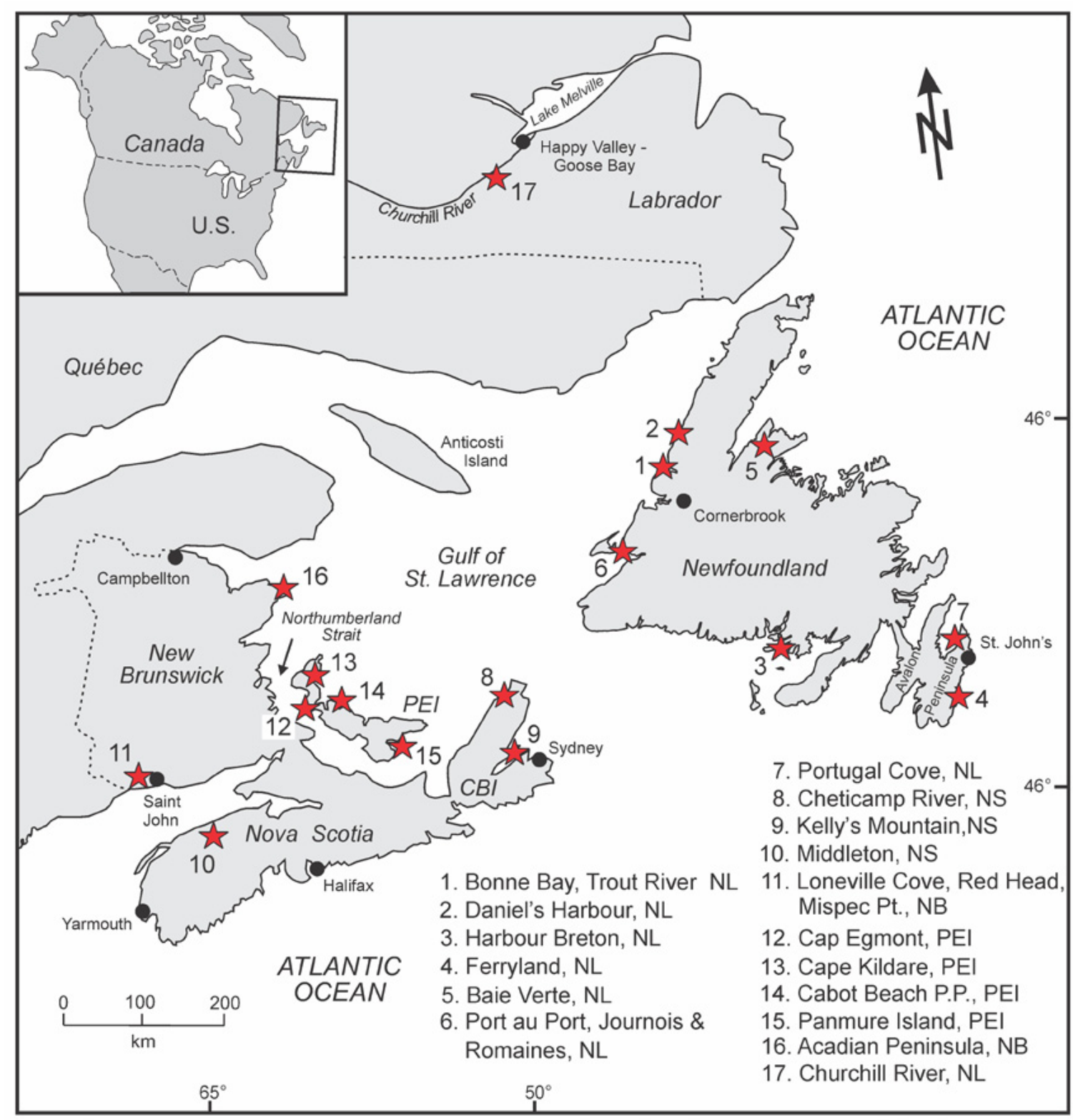

Figure 1. Location of selected slope failure sites discussed in detail in the text. $\mathrm{CBI}=$ Cape Breton Island, NB $=$ New Brunswick, $\mathrm{NL}=$ Newfoundland and Labrador, NS $=$ Nova Scotia, PEI = Prince Edward Island, P.P. $=$ Provincial Park.

The largest example of a sackung in Newfoundland is at Norris Point in Bonne Bay (Figs. 1, 2), where a rock mass estimated at $10 \mathrm{~km}^{3}$ has moved vertically by approximately $100 \mathrm{~m}$ (Fig. 2; Grant 1974). The head of the failure consists of a complex arrangement of scarps and fissures that align roughly parallel with regional jointing. Grant (1974) suggested that the failure of these dense ultramafic rocks (which were thrust over relatively weak shale and carbonate during the early Paleozoic) was caused in part by the oversteepening of the fjord wall during the last glaciation. The deep-seated failure occurred along the basal thrust contact and spreading resulted on all slopes along Bonne
Bay. Although the failure was initiated post-glacially, a more precise age of failure has not been determined. Visual examination from 1974 to 2003 suggested that no discernable movement was occurring during that time.

The causal mechanism for the Bonne Bay and other sackung throughout western Newfoundland remains uncertain. The locations of the sackungen do not coincide with fault escarpments, making tectonic disturbance unlikely. As the majority of sackungen are located adjacent to glacially over-steepened valleys, the failures appear to have developed in response to the removal of laterally supporting bedrock during glaciation, triggering lateral expansion 


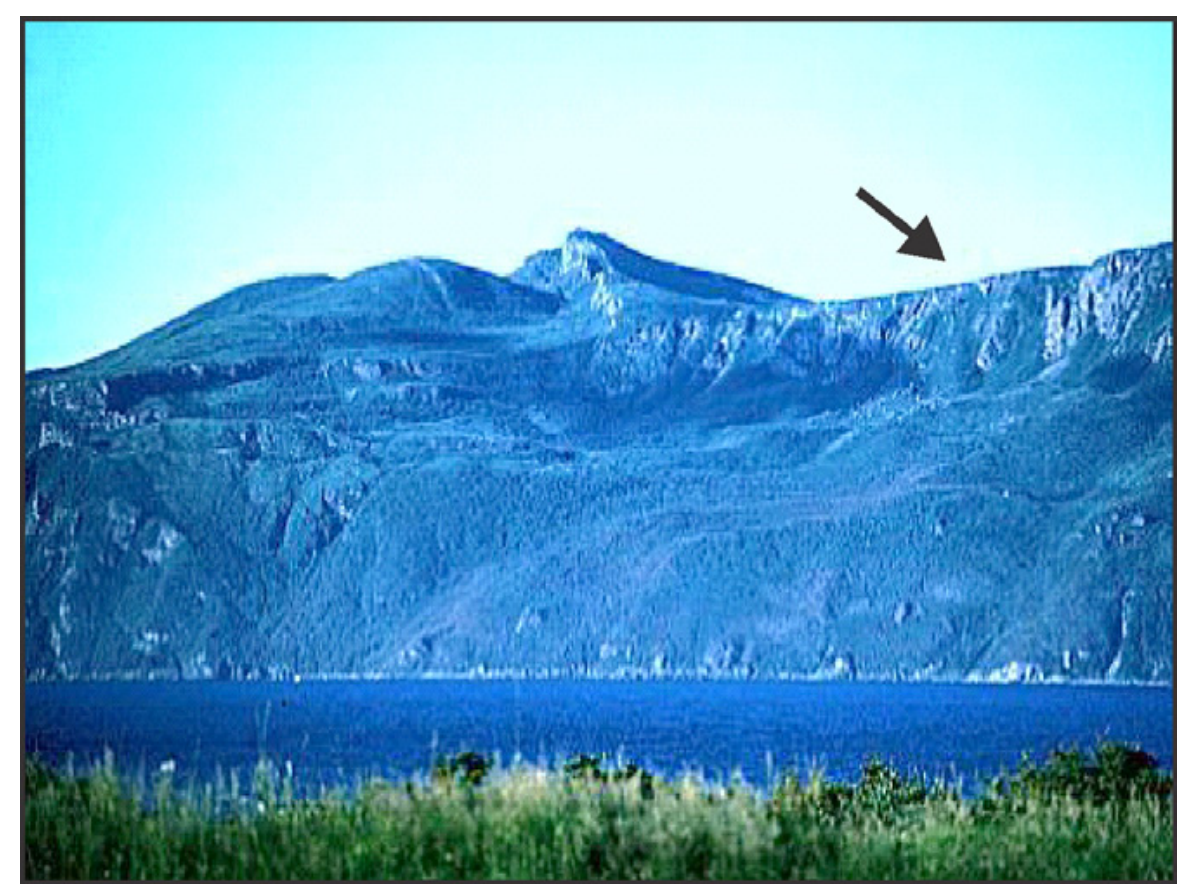

Figure 2. Sackung at Norris Point, Bonne Bay, Newfoundland. This is the largest of 24 examples of sackung in western Newfoundland identified by Grant (1974) and has an estimated volume of $10 \mathrm{~km}^{3}$. The arrow points to the headscarp.

when the ice ablated. Similar slope failures, albeit on smaller scales, are associated with valley down-cutting and "valley rebound" in other areas of the province (Babcock 1977).

Slow moving slope failure has occurred in the Advocate Mine, Baie Verte (Fig. 1). This large open-pit asbestos mine, developed in ultramafic rocks, is now abandoned; but in 1996, a large rotational slump developed in the pit wall. Since then it has been monitored in case it might affect the adjacent highway. The removal of lateral support during mining operations suggests a similarity with the Norris Point sackung and other examples in western Newfoundland.

\section{Rockfall}

Rockfall is a common process in Newfoundland and Labrador, due to the combination of relief, steep slopes resulting from glaciation, repetitive freeze-thaw conditions, and jointed, faulted and stratified rock-units with multiple planes of weakness. Most incidents involve single blocks, and those involving large volumes of debris are rare. The most serious reported incident, described below, relates to the unusual cave roof collapse at Ferryland (Figs. 1, 3, 4). Small-scale rockfall events have been widely reported and, although these rarely result in fatalities, they frequently cause damage and traffic delays, and are costly to clean up and remediate.

Numerous road cuts throughout Newfoundland have required stabilization to prevent rockfall. In the northeastern Avalon Peninsula, for example, outcrops are characterized by dipping, fractured and well-bedded latest Precambrian clastic strata. Excavations in these strata necessitate construction of retaining walls and/or stabilization of the fractured areas. Fractured slopes are subject to periodic failure by block fall, topple, and grain flow of previously disaggregated bedrock. Most failures are spatially restricted and initiated by frost wedging. Beddingplane slides are rare. During the springs of 1995, 1997, 2000, 2001 and 2002, several small rockfall events, each involving a maximum block size of about $2 \mathrm{~m}^{3}$ of rock, occurred along Pitts Memorial Drive in St. John's, obstructing traffic to a minor degree. The dip of the strata is opposed to the angle of the excavated slope, limiting the size of frost-wedged blocks. The potential for a major slope failure involving motorist casualties or reconstruction of the roadway is low, although a motorist was slightly injured after her car struck boulders on the road in the 2001 incident (Batterson et al. 2006).

Rockfalls have often affected property and dwellings below steep slopes, but surprisingly no structure-related deaths have been recorded. However, fatalities have occurred away from dwellings. The most severe injury in a residential setting occurred in Portugal Cove (Fig. 1), northwest of St. John's, where a woman lost a leg when a boulder struck her house. Fatal accidents have involved people at work or during recreational activities. A number of these accidents involved sea-cliffs and caves, a reflection of the working history of the province (Liverman et al. 2001). 


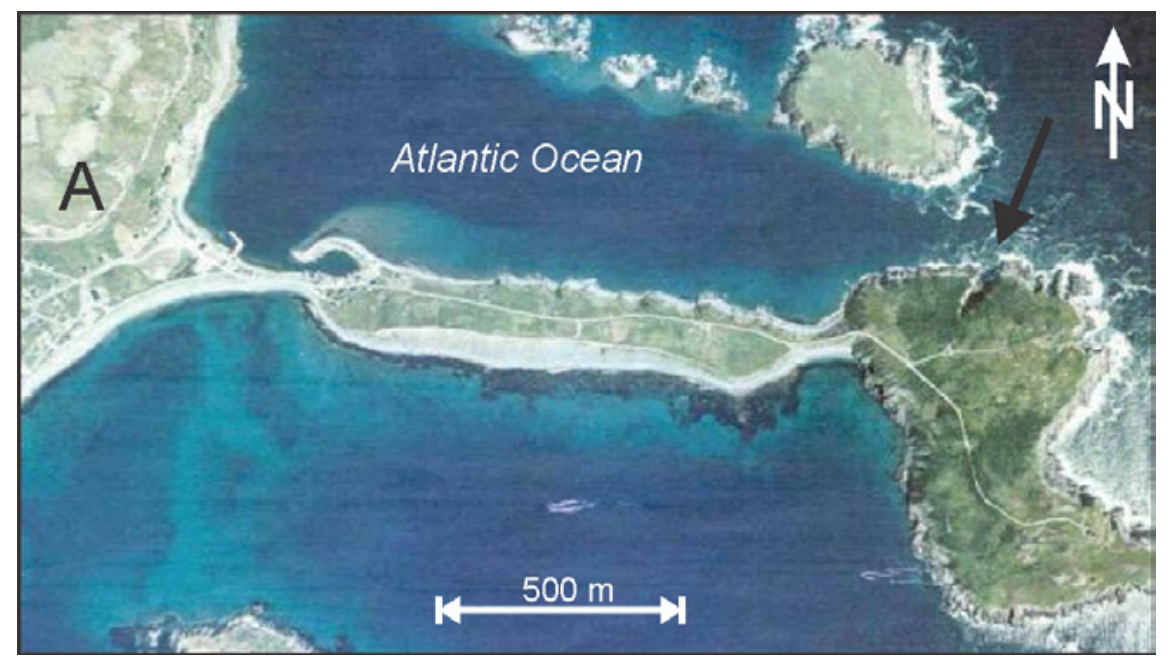

Figure 3. Ferryland Harbour, eastern Newfoundland. The village of Ferryland is to the left (A). The arrow points to "Deadman's Gulch", believed to be the site of a rockfall that killed 42 fishermen.

\section{Rockfall at Ferryland}

An intriguing story of what may be Canada's fourthworst landslide disaster was recounted in the Newfoundland Quarterly of March 1902 (White 1902). White reported a cave-in at Deadman's Gulch in Ferryland Harbour that apparently occurred in 1823 (Figs. 1, 3, 4). Although the report is detailed, White did not indicate the source of his information. Corroboration of the story has proved difficult - few newspapers were published at the time, and archives of those that were published have much of 1823 missing.

White describes "Deadman's Gulch", apparent on modern aerial photographs, as a gulch or notch in the cliff edge, extending several hundred metres inland from the coast on the south side of the Narrows that lead into Ferryland Harbour (Figs. 3, 4). White describes the incident as follows:

In 1823 or thereabouts it did not thus appear. It was then a mammoth cave, with an entrance to the ocean, in and out from which fishermen were accustomed to go from time to time to secure bait fish that used to frequent the gulch. But in the year of which I write forty-two fishermen in about 14-15 boats entered the cave to avoid being swamped by a severe storm of wind and rain, accompanied by the usual heavy sea which had overtaken them while on the fishing ground.

Residents of Ferryland heard a sound resembling a very loud clap of thunder, and the next morning:
They arrived at the Gulch (as gulch it was then) and discovered that during the night its roof had fallen in, burying the 42 fishermen - not one having been rescued. None of the bodies were ever picked up; having been buried, no doubt, beneath the crushing mass of stone which had fallen on them.

If this story is accurate, this is the worst geologically related disaster in the Province of Newfoundland and Labrador, and the fourth worst landslide disaster in Canadian history (Evans 2001), with more people being killed only in the Frank slide (75 fatalities in 1903), the Jane Creek disaster at Britannia Mine (54 fatalities in 1915) and the 1889 slide in Québec City (50 killed).

\section{Rotational slumps}

Rotational slumps and earth flows also occur in Newfoundland and Labrador, notably along the banks of the Churchill River in central Labrador (Fig. 1), where they have not had a significant impact on human activity, but are a major consideration for future development. Thick sequences of glaciomarine mud overlain by sands and gravel are found in the lower Churchill River valley, exposed in river cut-banks up to $40 \mathrm{~m}$ high. These banks are unstable, with widespread rotational slumps occurring within the glaciomarine mud. Similar stratigraphy and settings are found in other major valleys on the Labrador Coast, and similar slope failures are visible on aerial photographs. Large landslides have also occurred in areas of glaciomarine clay on the west coast of Newfoundland, notably at Romaines (Forbes et al. 1995) and Journois (Fig. 1). 


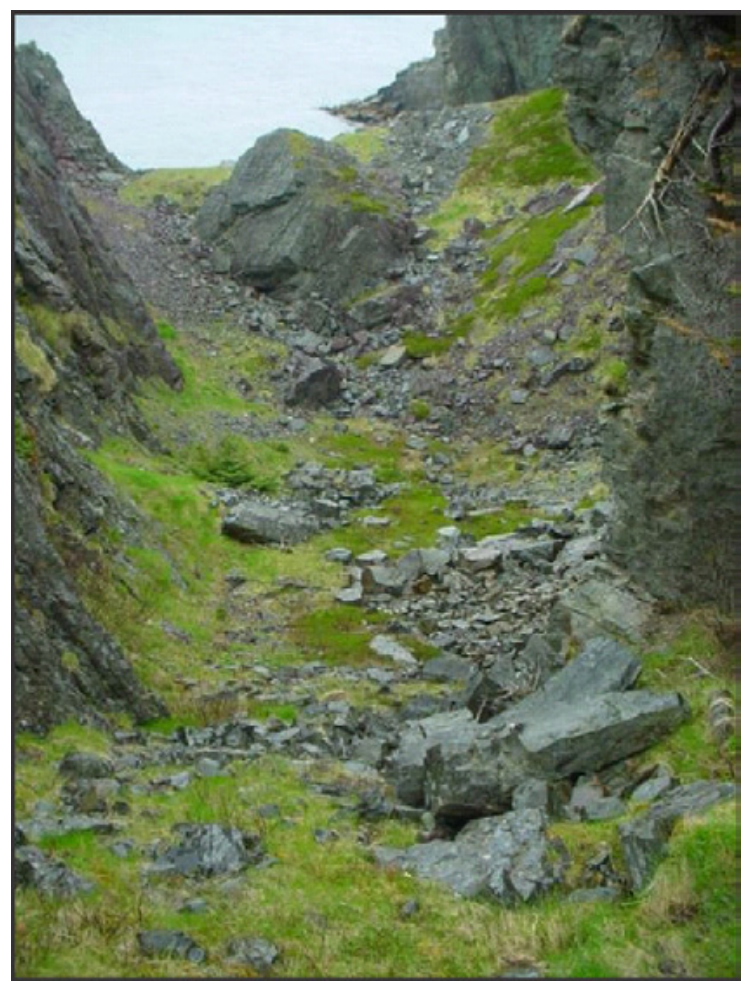

Figure 4. Deadman's Gulch at the entrance to Ferryland Harbour. Before the collapse, the site was believed to have been a sea cave that was frequented to catch baitfish and as a refuge during storms. The large boulder in the background is approximately $10 \mathrm{~m}$ across.

\section{Slope failure on the Lower Churchill River}

The lower Churchill River between Gull Island and Muskrat Falls shows numerous slope failures typical of many of the major valleys in coastal Labrador whose floors are underlain by glaciomarine silt and clay (Figs. 1, 5). As this area is the site of a proposed major hydro-electric dam, the potential for slope failures needs to be evaluated.

Three types of mass movement are identified in this area. The exposed glaciomarine sediments show relict deformation structures likely related to fluvial downcutting of exposed sediments shortly after a drop in sea-level that exposed the sediments. Active features include debris slides and debris-flow deposits. Sliding activity is initiated by fluvial undercutting, which over-steepens slopes formed mostly of glaciomarine silt and clay. Subsequent saturation likely plays a role in triggering movement. Sliding is both translational and rotational and can involve large volumes of sediment. The largest feature in the region has a surface area of approximately $3 \mathrm{~km}^{2}$ and involves about 60 million $\mathrm{m}^{3}$ of sediment. Sixteen other similar failures with surface areas of greater than $1 \mathrm{~km}^{2}$ and involving volumes greater than 20 million $\mathrm{m}^{3}$ are present in this stretch of the lower
Churchill River. Several of these, including the largest example described above, have occurred during the past 30 years, whereas other features are much older.

Debris flows are common in areas disturbed by sliding. Mudflows are observed at river level at the toes of larger slide features. Deformation structures beneath flow deposits indicate that such flows were rapid, shearing and loading underlying material.

The glaciomarine sediments of the lower Churchill form a significant geotechnical problem in construction, and further research is required to better understand their susceptibility to liquefaction and slope failure.

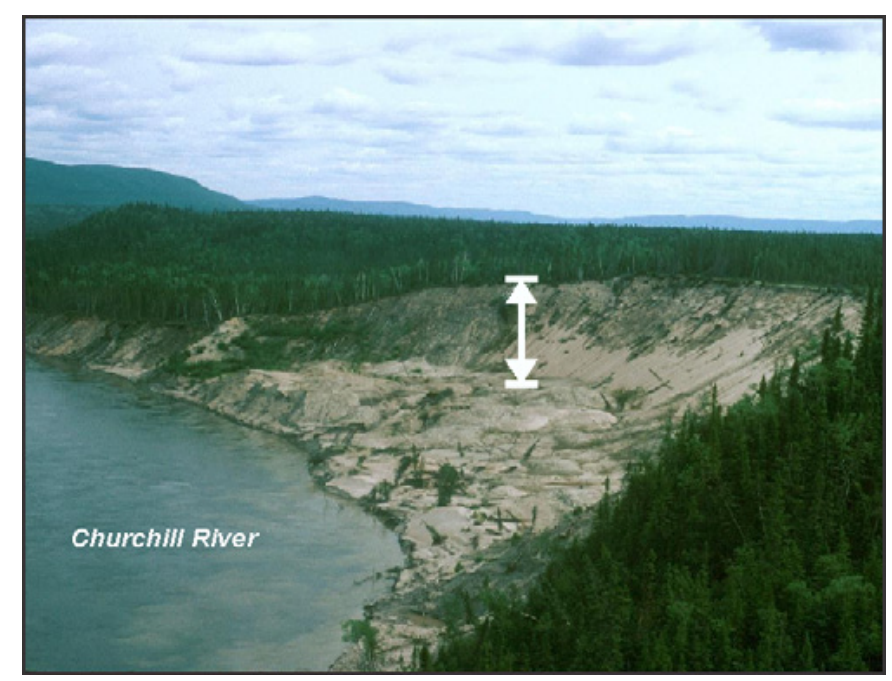

Figure 5. A large rotational slump on the east side of the lower Churchill River, Labrador. The active sediment is glaciomarine mud and overlying sand and gravel. Sliding was likely initiated by fluvial undercutting that oversteepened the slope. Scale bar is approximately $20 \mathrm{~m}$ high.

\section{Debris flows}

Debris flows are the most common destructive form of landslide in Newfoundland and Labrador. Landslide scars from debris flows are widespread and visible on aerial photographs. Debris flows are prone to occur where a combination of steep slopes and thick surficial sediment cover is present. In general, a relationship exists between their occurrence and exceptional precipitation events. Although glaciomarine mud is found in coastal areas of western Newfoundland, many of the documented examples involve till or re-mobilized colluvium. Debris flows have resulted in several fatal incidents, including those at Harbour Breton and on South Side Road in St. John's (Fig. 1).

On 1 August 1973, following several weeks of heavy rainfall, a debris torrent occurred at about 3 a.m. in a gully above the community of Harbour Breton (Fig. 1). The 
landslide is thought to have involved two events, separated by about 30 seconds (Nolan et al. 1973). The first flow originated from near the top of a $170 \mathrm{~m}$ high slope and is considered to have triggered the second major event, which lasted about three minutes. About $1500-2000 \mathrm{~m}^{3}$ of material were involved in the landslide (Nolan et al. 1973). The material was initially deposited on the road (at an elevation of about $12 \mathrm{~m}$ above sea level), which served as a temporary catch basin, but then overflowed and continued downslope to the shore, engulfing four houses in its path; four people in the houses were killed. There were previous reports of a landslide at the same site about 20 years earlier, and in 1971 a smaller debris flow had deposited enough sediment to block the road.

On 19 April 1994, a series of debris flow deposits blocked Riverside Drive in Corner Brook (Fig. 1). The flows originated on a north-facing slope in which bedrock is overlain by a compact glacial diamicton and fluvial sand and gravel. The cause of the debris flows was likely related to inadequate drainage from the adjacent newly constructed Trans-Canada Highway. During construction of the highway, a major drainage ditch was cut. Following a period of intense snowmelt, water normally carried by this ditch was re-directed through the subsurface to the adjacent slopes above Riverside Drive, triggering the debris flows. No injuries resulted, although Riverside Drive was closed until mid-summer.

A series of landslides occurred in the community of Trout River at the western edge of Gros Morne National Park between 6 and 13 June, 2009 (Figs. 1, 6, 7). The landslides displaced about $200 \mathrm{~m}^{3}$ of sediment, mostly silt and clay. The initial landslide occurred following a period of heavy rain (40 $\mathrm{mm}$ over 24 hours at Deer Lake, the nearest observing station). The second landslide occurred in the same area, with another part of the slope detaching, liquefying and flowing downslope (Fig. 6). Most of the material appears to have come from the vicinity of the headwall, flowing over the lower slope, which remained largely intact under the mud. The debris-flow deposit impacted a residence at the base of the slope, detaching it from its foundation and pushing it onto the adjacent road (Fig. 7). Three other residences at the base of slope were evacuated because they were assessed by provincial authorities to be at risk from further landslides. Residents of all four properties have subsequently been relocated.

\section{Landslides at Daniel's Harbour}

On 15 April 2007, a landslide occurred in the community of Daniel's Harbour on the Great Northern Peninsula; it covered an area of at least $5300 \mathrm{~m}^{2}$ and involved about $110000 \mathrm{~m}^{3}$ of material (Figs. 1, 8). The landslide resulted in

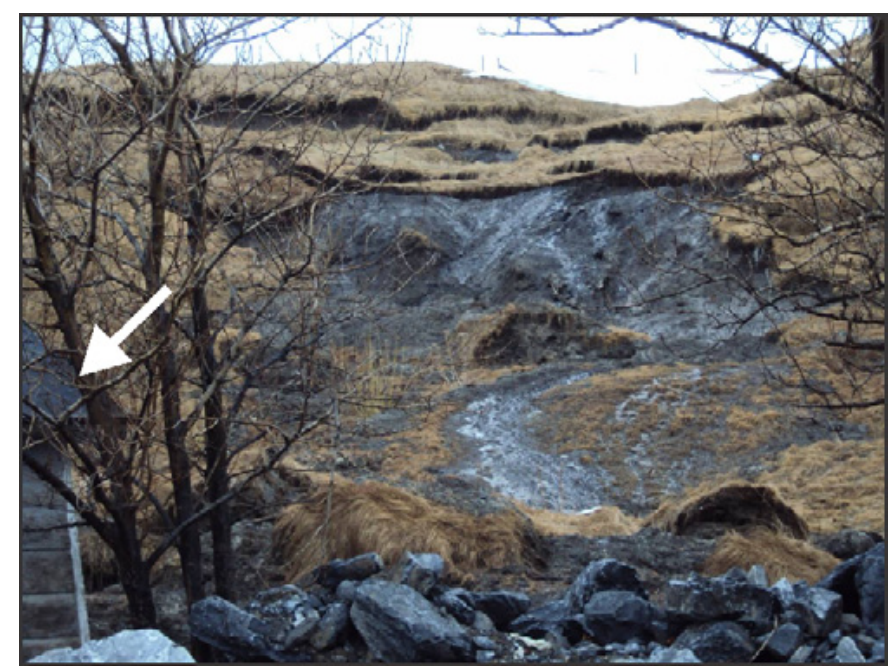

Figure 6. Debris flow deposit at Trout River, Newfoundland. The landslide displaced silt and clay and occurred following a period of heavy rain. Arrow points to house at right in Figure 7.

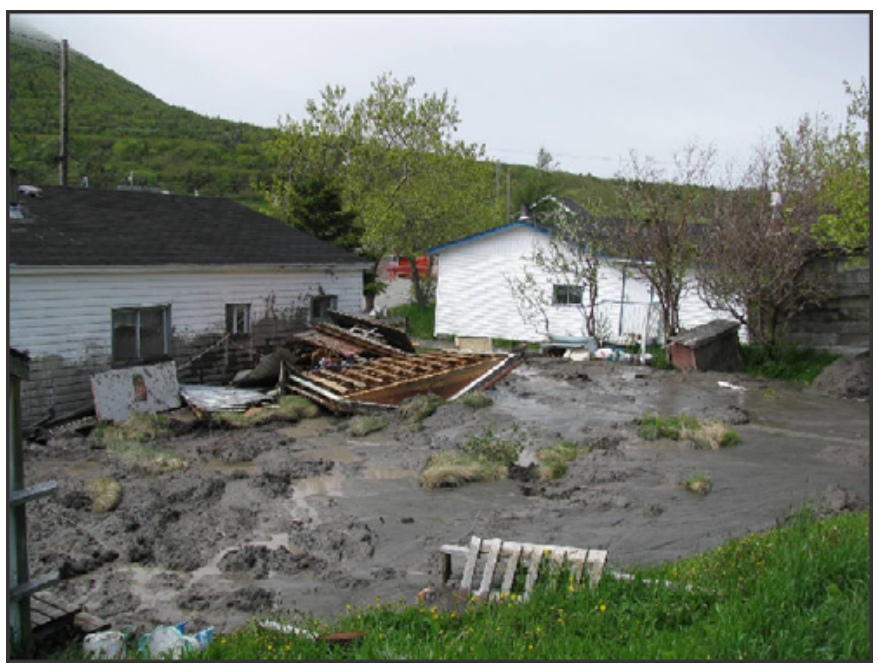

Figure 7. Debris flow deposit at Trout River, Newfoundland. The landslide, though small in volume, detached a house from its foundation and pushed it onto the adjacent road.

significant loss of property, including several residences, the subsequent removal of others from the site, and the eventual relocation of 23 families. The April 2007 landslide was preceded by a smaller event that affected the same area on 20 October 2006, which covered an area of approximately $1000 \mathrm{~m}^{2}$. The 2007 Daniel's Harbour landslide produced a large debris fan that extended about $60 \mathrm{~m}$ in front of the slide area (Fig. 8).

The landslides at Daniel's Harbour are the most recent of a series of similar events around that community. Aerial photographs show two large landslide scars, one north and one south of the recent slide. The southern slide covers 


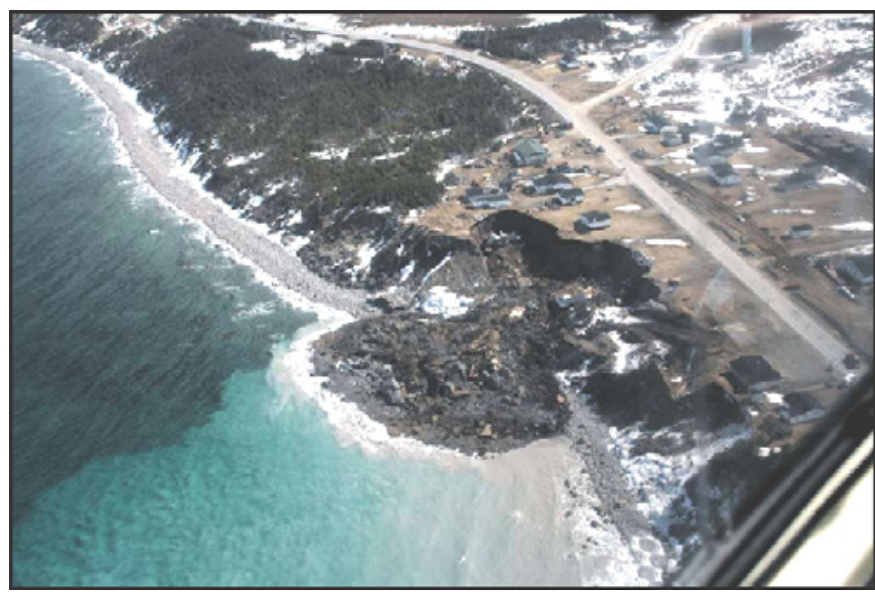

Figure 8. Landslide at Daniel's Harbour, Newfoundland. The slide was characterized as a combination of translational-slip failure and rotational-slip failure and occurred as a result of the saturation and subsequent loss of strength of a clay-rich layer underlying till.

approximately 1.28 hectares, whereas the slide to the north covers about 6.24 hectares. Both scars (now fully vegetated) are evident on the earliest aerial photographs of the area (1947) and neither is remembered by community residents. It cannot be determined if the scars represent a single landslide event or a series of landslides. Other considerably smaller landslides and landslide scars were noted north of Daniel's Harbour. Since 2007, a small landslide occurred on 18 June 2008 approximately $230 \mathrm{~m}$ south of the 2007 slide area. This later slide was a rotational slip type failure with a vertical scarp of 8 to $10 \mathrm{~m}$ along an estimated length of 10 to $20 \mathrm{~m}$. An estimated 1500 to $2000 \mathrm{~m}^{3}$ of material was dislodged during this slide.

The sediments exposed in the landslide area at Daniel's Harbour are glacial and post-glacial. The lowest observed unit is a poorly exposed silty clay bed approximately $1 \mathrm{~m}$ thick, overlain by a very compact glaciomarine diamicton with a silt-clay matrix and containing pebbles to boulders up to about $50 \mathrm{~cm}$ in diameter. The compact nature of the sediment is likely a combined result of its compression beneath ice and the presence of a high proportion of carbonate material, which acted as cement on the finegrained component of the sediment. The diamicton is overlain by $1-2 \mathrm{~m}$ of loose nearshore/beach sand and gravel (Proudfoot and St. Croix 1991), which were deposited during an interval of raised sea level following glacial retreat.

The 2007 landslide was a combination of a translational slip failure and a rotational slip failure, and likely occurred as the result of saturation and subsequent coastward movement of the clay-rich layer that underlies the compact till observed in the coastal exposures. As the clay-rich layer became saturated, it lost much of its cohesive strength. The pressure from the overlying till caused it to fracture along vertical planes, resulting in collapsed blocks. Following the initial failure, rapid release of pressure on the sediment produced subsequent vertical stress fractures that also failed as the clay-rich layer continued to be squeezed coastward. Small fracture planes oriented parallel to the surface were noted on eroded blocks on the debris-fan surface, confirming that pressure release was a significant process acting on the till.

The initial trigger for the landslide is uncertain. The landslide was not associated with a heavy rainfall event or unusually rough seas. This is confirmed by the presence of snow at the base of the cliffs along much of the coastline in the Daniel's Harbour area at the time of the landslide, which indicates that storm waves had not earlier impacted the coastline. A major storm affected the west coast of Newfoundland on 4 February 2007, when wave heights of $8 \mathrm{~m}$ were reported in Daniel's Harbour area. Perhaps wave impact at the base of the cliff from this event was the trigger by removing material from the base of the cliff; but the long interval of time between the storm and the landslide makes this scenario less likely. Other smaller slope failures along the coast north of Daniel's Harbour indicate that waves had undercut the coastline in places. Furthermore, the 2006 landslide at Daniel's Harbour was not associated with a significant rainfall event (though $7.5 \mathrm{~mm}$ of precipitation was recorded on October 16), or with high waves (based on local wind speeds).

\section{SLOPE FAILURE IN NOVA SCOTIA}

Nova Scotia also suffers from frequent landslides, particularly in the northwestern highlands of Cape Breton Island (Fig. 1; Spooner et al. 2010). Grant (1974, 1987, 1994) documented numerous incidents of rockfalls and topples from the cliffs that define much of the shoreline of the Cape Breton Highlands. Grant (1994) also noted extensive movement on the deep glacially and fluvially cut gorges found on plateaus. These gorges are bordered by steep rock cliffs from which rockfalls are a frequent event as witnessed by extensive talus slopes; some large-scale rock slumps (sackung) have also been recognized (Grant 1994). A large landslide appears to have taken place approximately 100 years ago along the Aspy Scarp, and another near the mouth of the Cheticamp River (Fig. 1; Grant 1994).

The largest recent landslide consisted of a series of slope failures that caused near complete destruction of the road at Kellys Mountain on Cape Breton Island in 1982 (Figs. 1, 9). A creosote wood culvert had been installed earlier to take runoff from the south side of the highway to a gully on the north slope, guiding the flow into St. Anns Harbour. The principal cause of the 1982 slide was likely water seepage from the deteriorated culvert. This, combined with water from spring thaw and rainfall, saturated the soil surrounding the culvert and caused erosion at the base of the slope, which 
resulted in a number of failures in late spring 1982. Bedrock underlying the gully may also have created natural failure planes for the saturated soil. The landslide was characterized as a translational slip failure that developed into a debris flow.

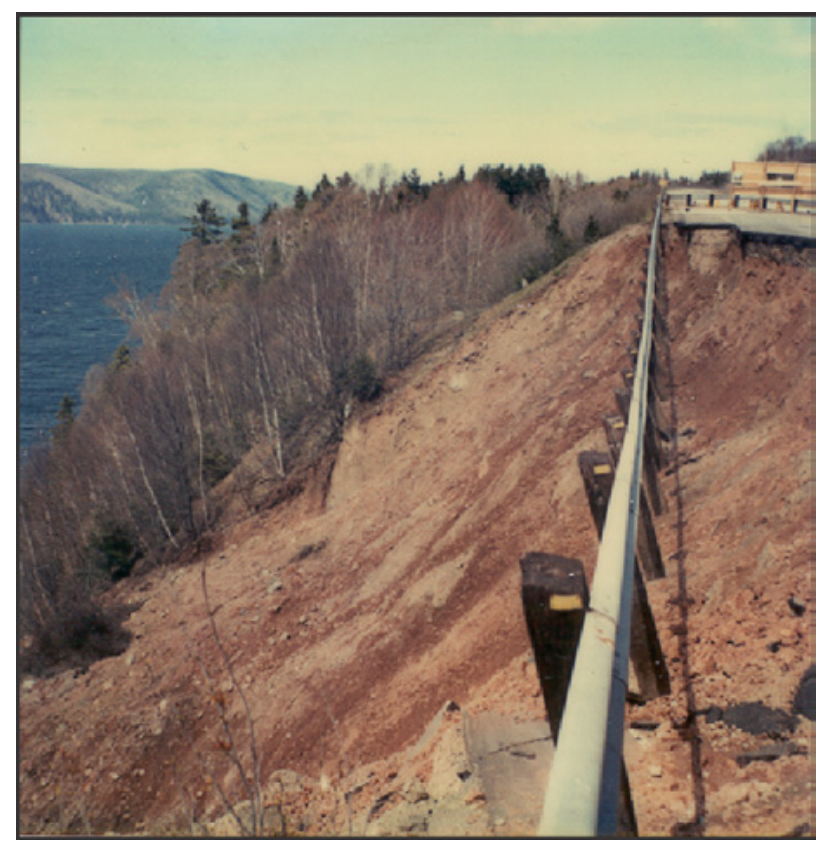

Figure 9. Debris-flow deposit at Kelly's Mountain, Cape Breton Island, Nova Scotia. This landslide has been characterized as a translational failure that developed into a debris flow.

Other smaller landslides frequently affect transportation routes in Nova Scotia, most commonly in spring, as thawing of frozen ground leaves slopes saturated. A large rotational slump occurred on the north side of Highway 201 near Middleton in late April 2003 and resulted in prolonged highway closure (Figs. 1, 10). Site investigation indicated that the Annapolis River was actively eroding the toe of a 20 m-high slope, which exhibited irregular topography and displayed evidence of previous movement, including tension cracks. The stratigraphy of the site is typical of the region: greater than $4 \mathrm{~m}$ of fluvial/glaciofluvial sand and gravel overlies sandy-clayey till and, in some cases, glaciomarine clay. Geotechnical analysis of the site indicates that two triggers most likely contributed to the slide: removal of toe support and a rise in the water table activating the failure plane between the outwash sediment and the impermeable clay-rich sediments.

Finck (1993), Grant (1994), and Wahl (2003) have identified numerous debris flow/avalanche scars in the Cape Breton Highlands (Figs. 1, 11, 12). These complex failures involve rock topple, rotational slip, translational sliding and flow (Finck 1993, Wahl 2003, Wahl et al. 2003). Although

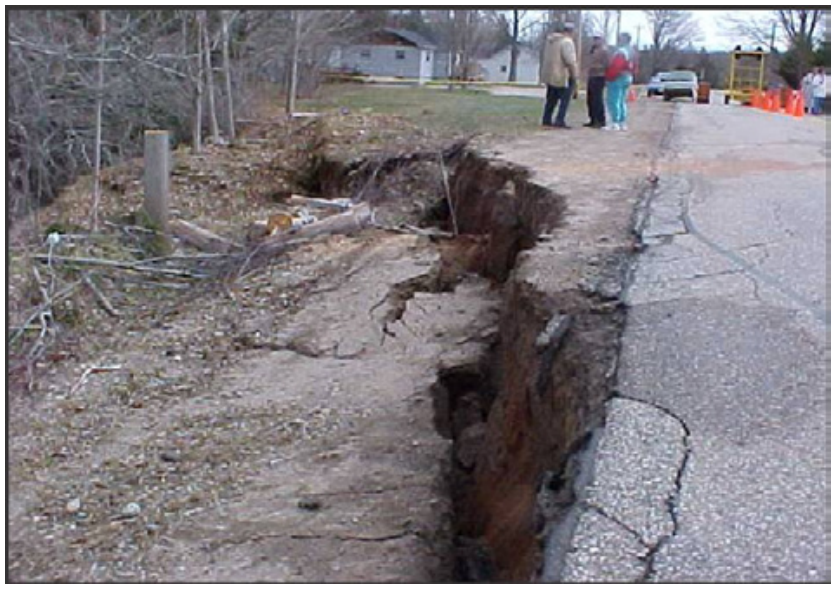

Figure 10. A large rotational slump in Middleton, Nova Scotia. This landslide was associated with fluvial erosion of $20 \mathrm{~m}$-high slope along the Annapolis River when the water table was elevated activating a failure plane between impermeable clay-rich till and overlying outwash sediment.

frequent, these landslides were not considered a significant hazard (Grant, 1994). Grant (1994) postulated that these landslides occurred as a result of mid- to late-spring snow avalanching or snowmelt, or possibly during rain-on-snow events when the ground was saturated and partly snow-free. Based on his observations, Grant (1994) determined that "hydrology is clearly the operative process" in the landslide activity. Wahl (2003) determined that two stratigraphic relationships are linked to most of the failures: the presence of highly compact, impermeable clay-rich lodgement till overlain by highly permeable colluvium; and impermeable weathered bedrock in the form of saprolite overlain by permeable colluvium. Both contact boundaries act as a slip surface, when groundwater accumulates at the colluvium/till or bedrock interface within the activation zone, producing an effective glide plane for initial translational movement.

Air-photograph interpretation indicates that an increase in landslide activity in Cape Breton Island has occurred during a 30-year period beginning in the 1960s. Examination of monthly precipitation trends led Finck (1993) to propose that significant increases in the precipitation levels during the month of April from 1980 to 1990 compared to the interval from 1961 to 1979 may have contributed to failure. Finck (1993), Wahl (2003), and Wahl et al. (2003) noted that root decay and loss of soil strength associated with treeroot rot from spruce budworm infestation may also have been of importance. They also commented on the strong spatial correlation between dead softwood stands and the occurrence of slope failure.

Preliminary archival research on the history of landslides in Nova Scotia has shown frequent minor incidents (Spooner et al. 2010). A preliminary review of articles from the 


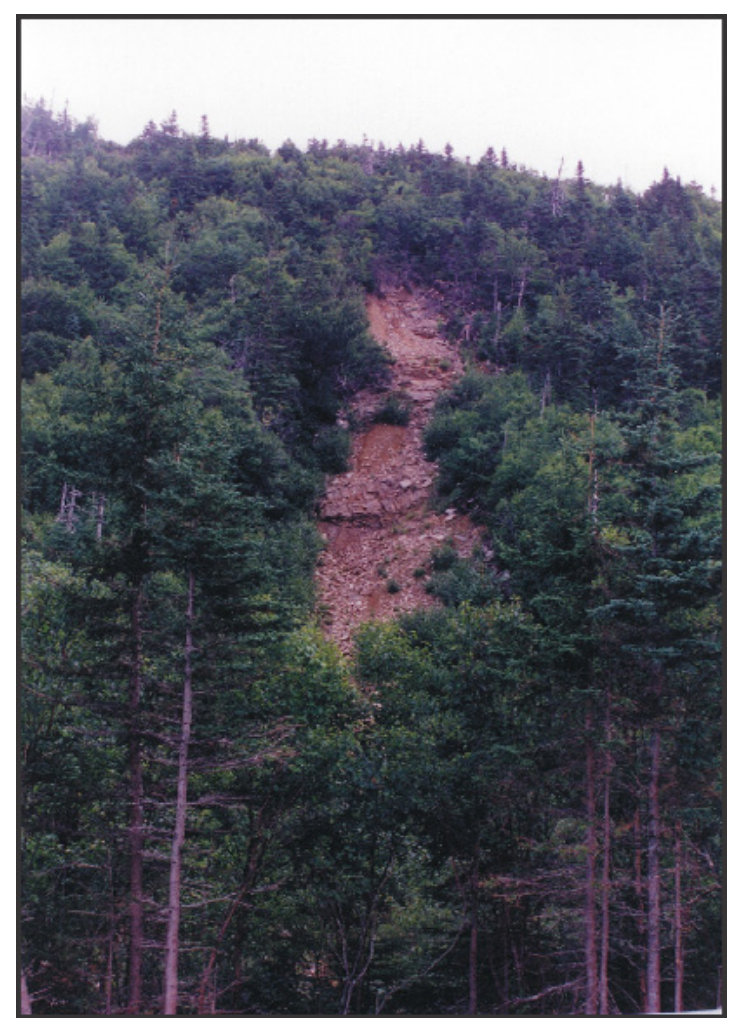

Figure 11. Debris-flow scar in the Cape Breton Highlands, Nova Scotia. These failures are typically complex and may involve rock topple, rotational slip, translational sliding and flow.

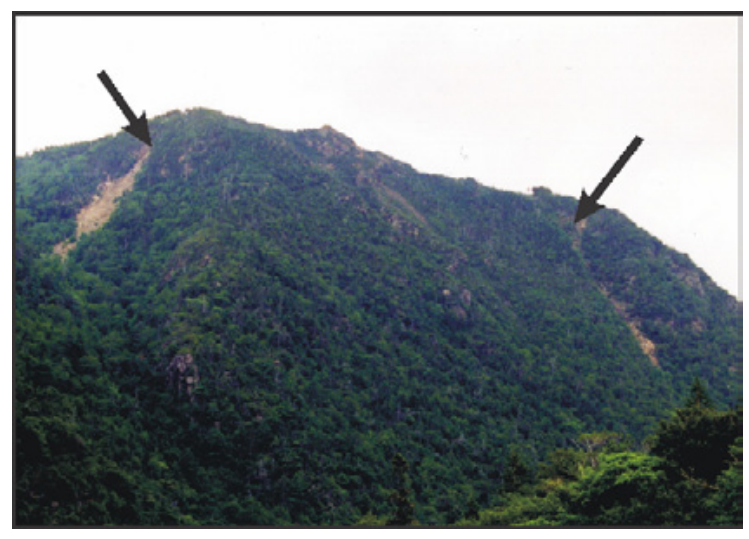

Figure 12. Debris-flow scars in the Cape Breton Highlands, Nova Scotia. Failure has been associated with excess water at the contact between colluvium and underlying weather bedrock or till.

Cape Breton Post from 1900 to 1925 indicates that railway transportation was frequently disrupted by minor landslides and washouts, usually following heavy rain.

\section{SLOPE FAILURE IN NEW BRUNSWICK AND PRINCE EDWARD ISLAND}

The combination of bedrock structure, glaciotectonic activity, frost wedging, and coastal erosion has resulted in the development of numerous small-scale landslide features in Prince Edward Island and New Brunswick, along with incremental retreat of coastal cliffs. As in other areas of Atlantic Canada, rockfalls, earthflows and small debris flows are common along highway cuts and steep river valleys. Larger slope failures have occurred in Quaternary glacigenic sediment at Lorneville Cove, near Saint John (Ruitenberg and McCutcheon 1978); in Quaternary marine sediment, diamicton, and the underlying Taylors Island Formation (Carboniferous; Barr et al. 2012); the Triassic Quaco Formation (Tanoli and Pickerill 1988) at Red Head and vicinity; and in Quaternary diamicton and the underlying Carboniferous Balls Lake Formation at Mispec Point and western Mispec Bay (Fig. 1).

The landslide at Lorneville mainly involved slumping of layered marine clay, silt and sand along a well-defined curved plane of sliding in contact with dipping, underlying bedrock over a distance of about $300 \mathrm{~m}$ (Ruitenberg and McCutcheon 1978). This slope failure may have been coincidental with a small regional earthquake (Broster and Burke 2011), but Wright (in Ruitenburg and McCutcheon 1978) reported that similar slides were previously known to have occurred in the Lancaster area, now a western extension of Saint John.

Overloading of post-glacial marine terraces and coastal bluffs due to suburban development and saturation of the deposits has further enhanced the susceptibility of the area to slope failure, particularly in Saint John. Elsewhere in the Saint John area and St. Croix Lowlands, Precambrian rocks are subject to frost wedging, and weathered surfaces undergo limited frost creep, although no significant failures are evident.

Failure of rocks along the Bay of Fundy involves exploitation of joints by frost action, in conjunction with undercutting by rising sea level and tidal action. This generally takes the form of rockfalls, block failure and toppling, although small rotational events locally develop along curved joint surfaces.

Theinterior of PrinceEdward Island and thelatePaleozoic lowlands of New Brunswick are not subject to significant slope failures due to their shallow topographic relief; for this reason, no notable events have been recorded in the Fredericton and Moncton areas (Broster 1998). Exceptions in these areas occur where man-made excavations produce steep cuts that expose joints and bedding planes that dip out of the exposure. Such occurrences are most dangerous when clay-filled steeply dipping joints are exposed due to removal of confining rock, as in open-pit mining (Park and Broster 1996).

Sugar Loaf Mountain near Campbellton has been the 
site of frequent small rock slides, but most slides occurring in remote areas of high relief in central New Brunswick go unreported. In general, slope failures in New Brunswick and Prince Edward Island have not posed significant threat to human life, largely because slope movements have been relatively small in urban centres and larger movements have occurred in uninhabited areas.

\section{Lorneville Cove landslide}

Between 8:00 a.m. on 26 November 1977 and 2 a.m. on the following day, a landslide occurred along the southwest shore of Lorneville Cove, on Saint John Harbour about 12 $\mathrm{km}$ west of the centre of Saint John. The slide developed in layered marine clay and silt, with sand interbeds overlying patches of diamicton and bedrock. The failure involved the slumping of a large wedge of the clay, silt and sand, which overlay bedrock. Ruitenberg and McCutcheon (1978) reported that the head scarp along the main failure plane demonstrated a vertical offset of about $4 \mathrm{~m}$, likely resulting from rotation of the major slump block and movement of the slide toe into the water. The failure plane as recognized by surface tension cracks that defined a circular head scarp over a distance of almost $300 \mathrm{~m}$, extended approximately $100 \mathrm{~m}$ back from the edge of the cove at its farthest point. The curved surface of sliding along the lower failure plane was estimated to be up to $10 \mathrm{~m}$ thick and in contact with bedrock along more than $80 \mathrm{~m}$ of sliding surface (Ruitenberg et al. 1976). The bedrock surface beneath the slide slopes seaward; throughout the area, this surface is streamlined, glacially polished, and intensely fractured.

The Lorneville Cove landslide occurred after a period of unusually high rainfall, and it is likely that the zone around the failure plane was saturated by groundwater. A seismic tremor was reported to have been felt by a local resident (Ruitenberg and McCutcheon 1978), but the archived data for the Dominion Observatory do not record an earthquake at the time (Broster and Burke 2011). The tremor was likely a product of the landslide.

\section{Coastal slope failures in the Gulf of St. Lawrence and Northumberland Strait}

Along the Gulf of St. Lawrence and Northumberland Strait coastlines, the most common form of slope failure involves erosion of late Carboniferous and Permian redbeds of the Bathurst Formation (Davies 1977) and Prince Edward Island Group (van de Poll 1989). Overlying Quaternary deposits are commonly involved, especially on Prince Edward Island but, with the exception of frost creep and small surface debris flows, are not instrumental in failure. Incremental slope failures result from frost action coupled with marine undercutting induced by rising sea level, which is about $3 \mathrm{~mm}$ per year throughout the region (Shaw et al. 1999). Locally, saturation of the bedrock and overlying Quaternary deposits resulting from agricultural practices (irrigation, disruption of drainage) has contributed to debris flow and creep failures.

Erosion is generally marked by incremental block failure, making generalizations from calculations of shortterm rates suspect. Rates for deep-seated bedrock failures have exceeded $80 \mathrm{~cm} / \mathrm{a}$ at several locations, including Cape Kildare (Fig. 1, Genest and Joseph 1989), Cape Gage, and Panmure Island (Fig. 1). On Prince Edward Island, erosion of bedrock-supported cliffs at rates of about $10-50 \mathrm{~cm} / \mathrm{a}$ is also evident at East Point (John Shaw, personal communication), High Bank, Point Prim, Fort Amherst National Historic Site, MacCallums Point (Catto 1998), Cap Egmont (Fig. 1), Cabot Beach Provincial Park (Fig. 1, Catto 1998), and Cape Tryon. Monitoring of coastal cliffs is relatively limited, consisting largely of spot checks. The potential scale and extent of coastal erosion of bedrock shores in Prince Edward Island, as well as along the Acadian Peninsula of New Brunswick, warrants attention (Fig. 1).

Joint systems in bedrock on Prince Edward Island resulted from a combination of lateral expansion due to removal of sediment by coastal erosion and vertical expansion due to glacioisotatic rebound. The rate of exploitation of these joints by mass wasting is controlled primarily by their orientation with respect to prevailing winds and the frequency of freeze-thaw cycles, but also by the amount of coastal undercutting of weaker shale and fine sandstone units. Freeze-thaw exploitation is dependent upon microclimate, which controls the number of cycles, and therefore the rates can vary substantially on opposite sides of an individual cove or peninsula. Another factor is the fracture pattern within the rock unit, which facilitates water percolation below the surface. The tensile strengths of all the rock units in Prince Edward Island are significantly less $(\sim 30 \%)$ than the stress induced by freezing. Where fracture planes are narrow or tortuous, or where multiple microfractures occur, confinement is more extensive, and more pressure can be induced. In the Prince Edward Island sedimentary successions, however, fracture surfaces tend to be planar and linear, and these (particularly along bedding planes) are relatively open, reducing the effectiveness of frost wedging. This factor is to some degree counterbalanced by the friability of the relatively weakly consolidated Carboniferous and Permian sediment and by the multitude of small vertical joints likely produced during glacioisostatic rebound.

In the stable tectonic environment of Prince Edward Island, sea-cliff morphology reflects the lithology, fracture pattern, glacioisostatic history, and terrestrial erosional processes (notably frost action and glaciation). Marine processes play a lesser role, as indicated by the similarity of 
jointing patterns and rates of coastal cliff development in Prince Edward Island to those developed inland in Atlantic Canada (Broster and Burke 1990; Park and Broster 1996; Catto and St. Croix 1997; White 2002).

\section{DISCUSSION}

The emphasis in this review on Newfoundland and Labrador examples is due in part to the extensive archival research performed in that province compared to others in the region. However, other reasons include its greater area, greater relief, and higher number of recorded fatalities. In addition, communities in Newfoundland and Labrador were mostly founded in locations chosen for access to good fishing and mining opportunities, whereas the other provinces had more diverse economies and many people settled inland in agricultural communities where a greater choice exists for dwelling locations; consequently, fewer people live in vulnerable locations.

Although a variety of types of slope failures have been documented, the majority of incidents that have caused loss of property, loss of life, or disruption to communication/ transportation corridors relates to debris torrents or flows and rockfall, usually block-topple involving single blocks. The most common response to landslide problems has been the implementation of remedial measures, including the installation of protective fencing, gabions, and other elements. Landslide hazard generally has not been incorporated into planning. This is partly because of lack of awareness of landslide hazard in communities, although slope stability is an important consideration in highway design.

The success of archival research in Newfoundland, combined with the number of occurrences discovered by preliminary archival searches in Nova Scotia, strongly suggests that a more systematic examination of newspaper records might yield a fuller record of landslides in Nova Scotia and New Brunswick.

Triggering of slope failures can be caused by several factors, but climatic variables are important, particularly for debris flows where heavy rainfall usually precedes slope failure. Rockfalls can also be triggered by exceptional precipitation, but also are affected by the freeze-thaw cycles. Many block-topples occur in spring, after a winter of repeated freeze-thaw cycles that have widened joints and fissures and lessened stability. Climatic change may affect landslide frequency in the future. Climate modeling suggests an increasing probability of extreme rainfall events in Atlantic Canada over the next 50 years, and landslide frequency may increase as a result.

The overall economic effect of landslides in the Atlantic Provinces is minor compared to those of the mountainous areas of British Columbia or densely populated areas underlain by Leda clay in Ottawa-St. Lawrence lowlands (Cruden et al. 1989). However, even a relatively minor slope stability problem along a busy transportation route can be costly. The cost of remediation of a failing slope on the Trans-Canada Highway at Gambo, eastern Newfoundland, was estimated at over $\$ 650000$ in 1993 (Batterson et al. 2006). The cost of protective fencing at Upper Island Cove following the 1999 rockfall event was estimated at about $\$ 1$ million. Disruption of transportation routes can also have an economic effect, as documented by Jackson (2002). Temporary closure of the Trans-Canada Highway or other major transportation routes in Atlantic Canada is rare, but has a major effect on the economy of the area.

The environmental effects of slope failures can also be considerable. In both Newfoundland and Nova Scotia, coarse-sediment flows have resulted in the modification of both floral and faunal habitats through the removal of vegetative cover and an increase in sediment influx into the river systems. The catastrophic input of sediments into local drainage networks can adversely affect both the water chemistry and the submarine ecosystem: in particular, the life cycle and spawning grounds of Atlantic salmon (Finck 1993; Schuster and Highland 2001)

Where fatalities occur and/or people are displaced from their homes, as at Harbour Breton, the social impact can be devastating.

\section{CONCLUSIONS}

Slope failures are common in areas such as Newfoundland and Cape Breton Island; these areas are characterized by steep slopes, emergent coastlines and active coastal erosion. Mass movements also occur along steep slopes in remote areas, as in the interior of New Brunswick, but go unreported due to the lack of habitation. The impact of landslides can vary, from none in remote areas to severe where communities and their residents are directly affected through relocation, loss of property or loss of life.

In general, landslides in Atlantic Canada are difficult to mitigate. The best strategy seems to be the relocation of residents; but the need to balance cost of such relocations against any proposed mitigation is recognized. The identification of potential landslide hazard is important from a municipal planning viewpoint. Landslide hazard mapping would be an important first step in the recognition of this natural hazard within municipalities. Such information should lead to restrictions to development in hazardous areas. Unfortunately even when similar mapping for flooding hazard has been available (e.g., for Badger, Newfoundland or Fredericton, New Brunswick), development in vulnerable areas has continued unabated. 


\section{ACKNOWLEDGEMENTS}

The research was funded by NSERC (IS), The Applied Geomatics Research Group (KW and DC) and an Acadia University Research Grant (IS). James Bridgeland, Ecologist at the Cape Breton Highlands National Park, graciously provided advice, data, and access to the park. The manuscript was improved by the suggestions of Andrée Blais-Stevens, Peter Bobrowski and Robert Fensome.

\section{REFERENCES}

Babcock, E.A. 1977. A comparison of joints in bedrock and fractures in overlying Pleistocene lacustrine deposits, central Alberta. Canadian Geotechnical Journal, 14, pp. 357-366. http://dx.doi.org/10.1139/t77-040

Barr, S.M., Park, A.F., Treat, R.L, White, C.E., and Miller, B.V. 2012. Carboniferous age confirmed for at least part of the Lorneville Group, Saint John area, New Brunswick. In Conference Program and Abstract Volume 2012, New Brunswick Exploration, Mining and Petroleum Conference. Nov. 4-6, 2012. New Brunswick Department of Minerals and Petroleum, 30.

Batterson, M.J., Liverman, D.G., and Taylor, D.M. 2006. Geological disasters in Newfoundland and Labrador. Geological Survey, Department of Natural Resources, Open File NFLD/2929, 85 p.

Broster, B.E. 1998. Aspects of engineering geology at Fredericton, New Brunswick. In Urban geology of Canadian cities. Edited by P.F. Karrow and O.L. White. Geological Association of Canada Special Paper 42, pp. 401-408.

Broster, B.E., and Burke, K.B.S. 1990. Glacigenic postglacial faulting at Saint John, New Brunswick. Atlantic Geology, 26, pp. 125-138.

Broster, B.E., and Burke, K.B.S. 2011. Geological and site specific factors influencing earthquake hazard assessment for New Brunswick. Atlantic Geology, 47, pp. 99-111. http://dx.doi.org/10.4138/atgeol.2001.004

Catto, N.R. 1998. Comparative analysis of striations and diamicton fabrics as ice flow direction indicators, Malpeque Bay region, Prince Edward Island. Boreas, 27, pp. 259-274. http://dx.doi.org/10.1111/j.1502-3885.1998. tb01420.x

Catto, N.R., and St. Croix, L. 1997. Urban geology of St. John's, Newfoundland. In Urban geology of Canadian cities. Edited by P.F. Karrow and O.L. White. Geological Association of Canada Special Paper 42, pp. 445-462.

Cruden, D.M., Bornhold, B.D., Chagnon, J.Y., Evans, S.G., Heginbottom, J.A., Locat, J., Moran, K., Piper, D.J.W., Powell, R. Prior, D.B., Quigley, R.M., and Thomson, S. 1989. Landslides: extent and economic significance in Canada. In Landslides: extent and economic significance.
Edited by E.E. Brabb. Balkema, Rotterdam, pp. 1-23.

Davies, J.L. 1977. Geological map of northern New Brunswick. Department of Natural Resources, Fredericton, Map NR-3, scale 1:250 000.

Evans, S.G. 2001. Landslides. In A synthesis of geological hazards in Canada. Edited by G.R Brooks. Geological Survey of Canada Bulletin 548, pp. 43-80.

Evans, S.G., and Clague, J.J. 2003. Origin and activity of antislope scarps in the mountains of southwestern British Columbia. Geological Society of America Abstracts with Programs, 35, September 2003, p. 310.

Finck, P.W. 1993. An evaluation of debris avalanches in the central Cape Breton Highlands, Nova Scotia. Mines and Energy Branch, Nova Scotia Department of Natural Resources, Paper 93-1, 65 p.

Forbes, D.L., Taylor, R.B., Oxford, R.B., Carter, R.W.G., and Shaw, J. 1995. Preliminary assessment of coastal erosion between Port au Port and Stephenville, St. George's Bay, west Newfoundland. Geological Survey of Canada, Open file 3082, 10 p. http://dx.doi.org/10.4095/203644

Genest, C., and Joseph, M-C. 1989. 88 centimetres of coastal erosion per year: the case of Kildare (Alberton), Prince Edward Island, Canada. GeoJournal. 18, pp. 297-303. http://dx.doi.org/10.1007/BF02301842

Grant, D.R. 1974. Terrain studies of Cape Breton Island, Nova Scotia and of the Northern Peninsula, Newfoundland. Report of Activities, Part A, Geological Survey of Canada, Paper 74-1A, pp. 157-160.

Grant, D.R. 1987. Quaternary geology of Nova Scotia and Newfoundland (including Magdalen Islands). International Union for Quaternary Research, XII INQUA Congress, Ottawa, Excursion Guidebook A-3/C-3, National Research Council of Canada, Publication 27525, $62 \mathrm{p}$.

Grant, D.R. 1994. Quaternary geology, Cape Breton Island, Nova Scotia. Geological Survey of Canada Bulletin 482, $159 \mathrm{p}$.

Isenor, F.M., Spooner, I.S., Wahl, K., Liverman, D., and Smith, J. 2005. Landslides and avalanches in Cape Breton Island, Nova Scotia, Canada. Canadian Quaternary Association (CANQUA) Biennial Meeting. Program with Abstracts, Winnipeg, Manitoba June 5-8, 2005, p. A36.

Jackson, L.E. Jr., 2002. Landslides and landscape evolution in the Rocky Mountains and adjacent Foothills area, southwestern Alberta, Canada. In Catastrophic landslides: effects, occurrence and mechanisms. Edited by S.G. Evans and J.V. de Graff. Geological Society of America Reviews in Engineering Geology, 15, pp. 325-244.

Liverman, D.G.E., Batterson, M.J., Taylor D., and Ryan, J. 2001. Geological hazards and disasters in Newfoundland. Canadian Geotechnical Journal, 38, pp. 936-956. http:// dx.doi.org/10.1139/t01-022

Liverman, D.G.E., Catto, N., Spooner, I., Wahl, K., and McAskill, G.W. 2003. Landslides in Atlantic Canada - a 
review. In Vulnerability of landslide risk to climate change. Edited by T. Kulkarin and A. Blais-Stevens. Proceedings from C-CIARN Landscape Hazards Workshop 2003, Vancouver, British Columbia, pp. 27-30.

Nolan, White, and Associates. 1973. Report on Harbour Breton landslide. Newfoundland Department of Mines and Energy. 30 p.

Park, A.F., and Broster, B.E. 1996. Influence of glacitectonic fractures on wall failure in open excavations: Heath Steele Mines, New Brunswick, Canada. Canadian Geotechnical Journal 33, pp. 720-731. http://dx.doi.org/10.1139/t96098-319

Proudfoot, D., and St. Croix, L. 1991. Landform classification and surficial geology of the Portland Creek map sheet, N.T.S. 12I/4. Newfoundland Department of Mines and Energy, Geological Survey Branch, Open File 012I/04/0212, Map91-163, scale 1:50 000.

Ruitenberg, A.A., McCutcheon, S.R., and Venugopal, D.V., 1976. Recent gravity sliding and coastal erosion, Devils Half Acre, Fundy Park, New Brunswick: geological explanation of an old legend. Geoscience Canada, 3, p. 237-239.

Ruitenberg, A.A., and McCutcheon, S.R. 1978. Engineering geology of the Lornville Cove Landslide. New Brunswick Department of Natural Resources, Open File Report 787,7p.

Schuster, R. L., and Highland L.M. 2001. Socioeconomic and environmental impact of landslides in the western hemisphere. United States Geological Survey Open-File Report 01-0276, $47 \mathrm{p}$.

Shaw, J., Taylor, R.B., Forbes, D.L., Solomon, S., and Ruz, M.-H. 1999. Sensitivity of the coasts of Canada to sealevel rise. Geological Survey of Canada, Bulletin 505. $114 \mathrm{p}$.
Spooner, I.S., Liverman, D., Catto, N., Batterson, M., McAskill, W., and Isenor, F. 2010. Mass wasting in Newfoundland and Nova Scotia - a review. 36th Annual Atlantic Geoscience Society Colloquium and Annual General Meeting Feb. 5-6, 2010, Wolfville, Nova Scotia, p. 38.

Tanoli, S.K., and Pickerill, R.K. 1988. Lithostratigraphy of the Cambrian-Lower Ordovician Saint John Group, southern New Brunswick. Canadian Journal of Earth Sciences, 25, pp. 669-690. http://dx.doi.org/10.1139/e88064

van de Poll, H.W. 1989. Lithostratigraphy of the Prince Edward Island redbeds. Atlantic Geology, 25, pp. 23-35.

Wahl, K. 2003. An assessment of landslide potential in the Cape Breton Highlands National Park: A GIS Approach. Unpublished M.Sc. Thesis, Acadia University, Wolfville, Nova Scotia, $175 \mathrm{p}$.

Wahl, K. Spooner, I.S., and Colville. D. 2003. An assessment of landslide potential in the Cape Breton Highlands National Park: a GIS approach. Atlantic Geology, 38, p.104.

White, J.W. 1902. Ferryland - what doth not appear in history. Newfoundland Quarterly, March 1902, pp. 11-12.

White, M. 2002. A preliminary assessment of slope stability and rockfall hazard, St. Brendan's, Bonavista Bay, Newfoundland. Unpublished MES project report, Memorial University of Newfoundland, St. John's, Newfoundland, $56 \mathrm{p}$.

Editorial responsibility: Robert A. Fensome 